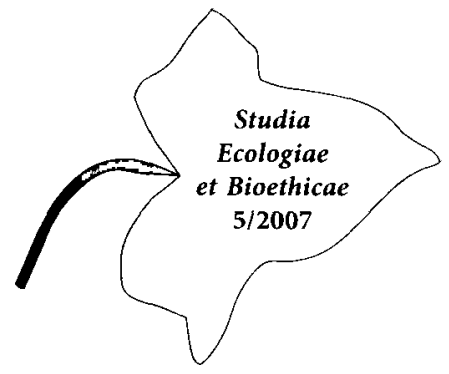

\title{
Szanse rozwoju spółdzielczości wiejskiej jako formy organizowania się rolników w Polsce w odniesieniu do warunków społecznych i gospodarczych w Unii Europejskiej
}

Katolickie nauki społeczne opierają się głównie na zasadach uniwersalistycznego humanizmu chrześcijańskiego, personalizmu chrześcijańskiego, dobra wspólnego i pomocniczości, humanistycznej struktury każdej ludzkiej społeczności, proporcjonalności w rozwoju życia społecznego. Ważnym warunkiem jest zachowanie idei humanistycznych w porządku społecznym: „(..) społeczność jest tworem ludzi wchodzących w jej skład i tylko o tyle i w takim stopniu jest ona prawdziwą społecznością, o ile jej członkowie świadomie i aktywnie uczestniczą w jej życiu i działaniu. (...) W przeciwnym razie jest ona pseudospołecznością, jest w gruncie rzeczy narzędziem zniewolenia człowieka i jego wyzysku"1.

Kościół katolicki rozpowszechnia w swoim nauczaniu prawa osoby ludzkiej i zasady ładu społecznego: prawdy, sprawiedliwości, miłości i wolności, które zostały ogłoszone m.in. w orędziu radiowym Piusa XII w 1942 roku, encyklice Jana XXIII Pacem in terris, Mater et magistra, Powszechnej Deklaracji Praw Człowieka Organizacji Narodów Zjednoczonych.

Zgodnie z zasadami etyki społecznej wartościami ważnymi dla człowieka są praca i własność. Dzięki pracy człowiek może się doskonalić i przekształcać świat. Praca posiada niezbywalną godność, a godność osoby ludzkiej jest podstawą praw człowieka. Prawo własności stanowi dla człowieka podstawę i przesłankę do korzystania $z$ wolności.

Etyka gospodarcza różni się od etyki ogólnej tylko stopniem ogólności przedmiotu materialnego. Etyka ogólna obejmuje swym zakresem wszystkie czyny ludzkie. Przesłaniem etyki gospodarczej jest moralna ocena działań gospodarczych człowieka w odniesieniu do struktur i instytucji społecznych.

J. MAJKA, Komentarz do encykliki Jana XXIII Mater et Magistra, (W:) Jan XXIII: Mater et magistra, Wroclaw 1997, s. 110. 
W etyce społecznej obowiązuje norma wyrażenia przez pracę powszechnej solidarności. Solidarność jest wspólnym działaniem ludzi, którzy znajdują się w podobnej sytuacji i chcą usunąć niesprawiedliwość ${ }^{2}$. Najwyższe prawo filozofii społecznej stanowi, że „ (...) to co jednostka $z$ własnej inicjatywy i własnymi siłami może zdziałać, tego nie wolno jej wydzierać na rzecz społeczeństwa. (...) Każda akcja społeczna (...) winna pomagać członkom organizmu społecznego, a nie niszczyć ich lub wchłaniać” 3 . Jan XXIII wskazał zasadę prawdy jako główną zasadę kształtowania relacji społecznych w społecznościach: „(..) o prawdzie w życiu społecznym, ma na myśli także prawdę w znaczeniu moralnym, prawdę, której przeciwieństwem jest obłuda, kłamstwo i niczym nie uzasadniona tajemnica w działalności społecznej, zwłaszcza w działalności władzy społecznej. (...) Kłamstwo bowiem i tajemnica znamionują traktowanie człowieka w życiu społecznym jako przedmiotu, wyłącznie jako środka do osiągania celów, podczas gdy człowiek jest i musi zawsze pozostać kimś współtworzącym życie społeczne, podmiotem świadomego oddziaływania na to życie; a to domaga się rozumienia wszystkich jego spraw i dostępu do najniezbędniejszych informacji"4.

Warunkiem sprawiedliwości społecznej jest wzajemne dostosowanie i uzupełnianie się rozwoju gospodarczego i postępu społecznego ${ }^{5}$.

Działalność gospodarcza podejmowana przez obywateli powinna być wspierana w różny sposób przez państwo. Wsparcie ze strony państwa może przybierać różne formy prawne, finansowe m.in. dla różnego typu organizacji społecznych, spółdzielni, grup producenckich rolników ${ }^{6}$. Przesłaniem rolników, którzy zakładali zrzeszenia w okresie zaborów, był rozwój ich gospodarstw i postęp społeczny i ekonomiczny społeczności polskiej?.

2 Słownik katolickiej nauki społecznej, red. nauk. Władysława Piwowarskiego, Warszawa 1993, s. $48,168,171$.

3 Pius XI, Quadragesimo Anno. Na podstawie: JAN XXIII, Mater et magistra....s. 23-24.

4 J. MaJKA, Komentarz do encykliki Jana XXIII Pacem in terris, (W:) Jan XXIII, Pacem in terris. Wrocław 1997, s. 81.

5 JAN XXIII, Mater et magistra..., S. 14.

6 Stefan Bratkowski jako możliwość rozwoju wsi wskazał formę kredytowania działalności gospodarczej dla mieszkańców wsi: „(...) grunty wiejskie staną się wartościową podstawą systemów kredytowych, które - mam nadzieję - odbudujemy w Polsce dzięki starym, polskim doświadczeniom". Stefan Bratkowski: Zamiast krakać, czyli to wieś ma przyszłość. Strona $\mathrm{z}$ dnia 8 maja 2007 roku. http://www.fcp.edu.pl/site2/bibl/b019.html.

7 Stefan Bratkowski stwierdzil, że „(...) wielkopolską wieś uczyli zaradności jej właśni księża. To jest możliwe i dziś; współcześni nasi proboszczowie nie muszą już sami prowadzić banków spółdzielczych i kółek rolniczych, ale mogliby uczyć - zaradności (jak robi to paru moich przyjaciól proboszczów w różnych punktach kraju). Niestety, ich samych nie uczą tego seminaria duchowne". Stefan Bratkowski: Zamiast krakać, czyli to wieś ma przyszłość. Strona z dnia 8 maja 2007 roku. http://www.fcp.edu.pl/site2/bibl/b019.html. 


\section{Rys historyczny spółdzielczości w Polsce}

W Polsce spółdzielnie mają dwustuletnią tradycję. Inicjatorem powstawania spółdzielni był Stanisław Staszic, który w 1816 roku założył w swoim majątku Hrubieszowskie Towarzystwo Rolnicze Ratowania się Wspólnie w Nieszczęściu. Towarzystwa rolnicze były powoływane w każdym zaborze. W zaborze pruskim w 1848 roku powołano Ligę Polską, w zaborze austriackim w 1845 roku powstały Towarzystwo Gospodarki we Lwowie, Towarzystwo Rolnicze w Krakowie i Galicyjskie Towarzystwo Gospodarskie. W zaborze rosyjskim pierwsi fachowcy rozpoczęli działalność edukacyjną i doradczą pod koniec XIX wieku, prawo zrzeszania się otrzymali dopiero w 1906 roku.

Poważny wpływ spółdzielczości na rozwój gospodarczy i społeczny potwierdza fakt, że była zagadnieniem ważnym pod względem socjologicznym i ekonomicznym rozważanym przez przedstawicieli przeciwstawnych nurtów społecznych jak konserwatyzm i socjalizm. Konserwatyści uważali, że w spółdzielniach konkurencja była zastępowana współdziałaniem członków spółdzielni. Poglądy Edwarda Abramowskiego profesora Uniwersytetu Warszawskiego są zbieżne $z$ konserwatywnymi w jego założeniach, że rewolucja społeczna powinna być połączona $\mathrm{z}$ rewolucją moralną opartą na solidarności i kooperatywach ${ }^{8}$.

Edward Taylor ekonomista ocenił, analizując prawo spółdzielcze w innych krajach europejskich, że polska ustawa o spółdzielczości z 1920 roku trafnie oddaje istotę gospodarczą i społeczną spółdzielni'. Znaczny wkład w rozwój spółdzielczości po odzyskaniu niepodległości wnieśli m. in. dr Franciszek Stefczyk, Romuald Mielczarski, Stanisław Wojciechowski, Zygmunt Chmielewski.

W Polsce w okresie międzywojennym spółdzielczość rolnicza osiągnęła znaczącą pozycję w odbiorze społecznym, czego potwierdzeniem były spółdzielnie branżowe działające głównie w czterech sektorach: oszczędnościowo-pożyczkowe, mleczarskie, ogrodniczo-pszczelarskie i zaopatrzenia i zbytu. W 1929 roku powstało Centralne Towarzystwo Organizacji i Kólek Rolniczych ${ }^{10}$. W latach trzydziestych XX wieku na terenie całego kraju były zakładane izby rolnicze ${ }^{11}$.

8 J. Auleytner, Polska polityka spoteczna. Ciaglość i zmiany. Warszawa 2004 s. 67. E. Abramowski wyraził swój pogląd w tej sprawie w dwóch broszurach: „Idee społeczne kooperatyzmu” wydanej w 1907 roku, „Kooperatywa jako sprawa wyzwolenia ludu pracującego” z 1912 roku, był współzałożycielem miesięcznika „Społem”, organu prasowego Towarzystwa Kooperatystów.

9 E. TAYLOR, O istocie spóldzielczości. Poznań 1946 s. 23. Ustawa o spółdzielczości z 1920 r. nowelizowana obowiązywała do 1961 roku.

10 CTOiKR został powołany przez członków Centralnego Towarzystwa Rolniczego i Centralnego Związku Kółek Rolniczych, które zrzeszyły się w jeden związek.

$"$ B. M. WaWrzyniaK, Doradztwo i postęp w rolnictwie polskim. Włocławek 2003 s. 45. 
W latach 1946-1947 Izby Rolnicze zostały zlikwidowane, a ich kompetencje zostały przekazane Związkowi Samopomocy Chłopskiej. Od połowy 1948 roku była intensywnie przeprowadzana kolektywizacja wsi.

W latach 1946-1950 w warunkach wprowadzania gospodarki planowej wszystkie spółdzielnie branżowe zostały zlikwidowane, a na ich miejsce były zakładane spółdzielnie uniwersalne, które reaktywowano po październiku 1956 roku $^{12}$.

W okresie realnego socjalizmu spółdzielnie były traktowane na polskiej wsi jako odmiana kolektywizacji ${ }^{13}$, „Obowiązkowe dostawy oduczyły wielu rolników liczenia kosztów i rynkowych postaw, różnorodne zaś formy kolektywizowania wsi wywołały alergię na samo słowo "spółdzielnia" ${ }^{14}$.

W encyklice „Mater et magistra” Jan XXIII odniósł się do polityki gospodarczej i społecznej prowadzonej w krajach socjalistycznych: „Wydarzenia bowiem, które miały gdzieniegdzie miejsce, nauczyły nas, że tam, gdzie brak prywatnej inicjatywy jednostek, władza państwowa przekształca się w tyranię; ponadto zamiera tam aktywność w dziedzinie życia gospodarczego oraz dostrzega się braki w zakresie dóbr konsumpcyjnych oraz tych, które służą zaspokojeniu nie tyle materialnych, co duchowych potrzeb. Inicjatywa i zapobiegliwość jednostek sprzyja bowiem w szczególny sposób wytworzeniu tych dóbr i usług" ${ }^{15}$.

$\mathrm{W}$ krajach bloku socjalistycznego prywatne gospodarstwa rolne były tylko w Polsce i Jugosławii.

\section{Problemy spółdzielczości w okresie transformacji ustrojowej}

Spółdzielnia, w rozumieniu polskich spółdzielców, jest autonomicznym zrzeszeniem osób, które zjednoczyły się dobrowolnie w celu zaspokojenia swoich

12 J. TURowski, Spóldzielnie rolnicze w Polsce w świetle zasad spolecznych pomocniczości i solidarności. (W:) Spółdzielczość rolnicza w gospodarce rynkowej (doświadczenia i przyszłość), red. nauk. Eugeniusza Pudełkiewicza, Zbigniewa T. Wierzbickiego, Warszawa 1993, s. 196, [materiały Międzynarodowego Sympozjum „Doświadczenia i przyszłość spółdzielni rolniczej w gospodarce rynkowej" Miedzeszyn k. Warszawy, 17-19 lutego 1993 r.].

13 S. Wojciechowski ocenił rosyjskie spółdzielnie spożywców zakładane przez komunistyczny rząd w ZSRR jako związki przymusowe, natomiast uczestnictwo w spółdzielni jest dobrowolne. S. Wojciechowski, Kooperacja w rozwoju historycznym. Warszawa 1923, s. 103. W artykułach 15 i 16 Konstytucji Polskiej Rzeczypospolitej Ludowej zapisano, że spółdzielczość miała zapewnioną wszechstronną pomoc państwa, ponadto spółdzielczość byla regulowana przez ustawę z dnia 17 lutego 1961 roku o spółdzielniach i ich związkach (Dz. U. nr 12 poz. 61) zmieniona ustawą z dnia 17 grudnia 1974 roku (Dz. U. nr 47, poz. 281). Powyższa ustawa byla wspólnym aktem prawnym dla wszystkich typów spółdzielni i związków spóldzielczych.

14 B. Fedyszak-RadziejowsKa, Jak polska wieś przez Brukselę do Polski wracala, (W:) III Rzeczpospolita w trzydziestu odsłonach, pod. red. A. Kostarczyk, Warszawa 2004, s. 267.

15 JAN XXIII, Mater et magistra..., s. 25. 
wspólnych aspiracji i potrzeb ekonomicznych, społecznych i kulturalnych poprzez współposiadane i demokratycznie kontrolowanie przedsiębiorstw. Prawo spółdzielcze jest zawarte w ustawie $\mathrm{z}$ dnia 16 września $1982 \mathrm{roku}^{16}$.

W pierwszych latach transformacji gospodarczej i społecznej w Polsce większość spółdzielni została przekształcona z powszechnych spółdzielni w spółki wąskich grup społecznych. Te działania zapoczątkowały załamanie się spółdzielczości socjalistycznej w warunkach gospodarki rynkowej, szczególnie niekorzystne skutki dotknęły spółdzielczość rolniczą. Najpoważniejszą konsekwencją ustawy z 20 stycznia 1990 roku o zmianach organizacji i działalności spółdzielczości było zerwanie dotychczasowych więzi gospodarczych, w tym utrata sieci handlowych i stałych odbiorców $w^{17}$. Trudności wyniknęły z zaliczenia spółdzielczości do gospodarki uspołecznionej do końca 1990 roku, w porównaniu do sektora prywatnego spółdzielnie jeszcze dłużej musiały ponosić dodatkowe obciążenia podatkowe i inne opłaty. Ustawa z 20 stycznia 1990 roku obligowała spółdzielnie do lustracji oraz na półtora roku wprowadziła zakaz zrzeszania się spółdzielni. Ostatni wymóg był niezgodny z konstytucją. Spółdzielnie musiały w krótkim terminie (do trzech miesięcy) wybrać organy statutowe pod rygorem ich rozwiązania. Sprzeciw budziła ingerencja administracji państwowej. Likwidatorów powoływało i rozliczało Ministerstwo Finansów. W celu przeciwstawienia się tym działaniom ze strony organów państwa spółdzielcy powołali Komitet Obrony Spółdzielczości ${ }^{18}$. Publicysta zajmujący się sprawami społecznymi skomentował: „Dzięki niefachowej ustawie spółdzielczej tzw. spółdzielnie mleczarskie zostały spółkami lub spółdzielniami pracowników mleczarni”'19.

W pierwszym okresie transformacji ustrojowej i gospodarczej bardzo negatywną konsekwencją dla spółdzielni rolniczych były nieoczekiwane zmiany $\mathrm{w}$ warunkach kredytowania. Spółdzielnie nie mogły korzystać $\mathrm{z}$ linii kredytowych uruchamianych dla gospodarstw indywidualnych $\mathrm{z}$ funduszy pomocowych, mimo że reprezentowały własność prywatną ${ }^{20}$.

Obecne wymagania - np. maksymalizacji zysku - jakie stawiają sobie w warunkach gospodarki wolnorynkowej spółdzielnie, które były zakładane jeszcze w okresie socjalizmu są sprzeczne ze wszystkimi prawie zasadami spółdzielczości i wartościami społecznymi ruchu spółdzielczego.

16 Ustawa z dnia 16 września 1982 r. Prawo spółdzielcze. Dz.U. $1982 \mathrm{Nr} 30$ poz. 210. Wszystkie ustawy i ich nowelizacje związane ze spółdzielczością zostały przedstawione w bibliografii.

17 Nastąpiła likwidacja nadbudowy organizacyjnej spółdzielni, większa część majątku została przekazana nowo powstającym spółdzielniom pracy. E. SKAwIŃsKA, Spóldzielczość wiejska w warunkach integracji rynku produktów żywnościowych Polski i Wspólnot Europejskich. Toruń 1997 s. 44.

18 Ibidem s. 45.

19 S. BRATKOWSKI, Zamiast krakać, czyli to wieś ma przyszłość. Strona z dnia 8 maja 2007 roku. http://www.fcp.edu.pl/site2/bibl/b019.html

20 Ibidem s. $48-50$ 
Zapis w artykule 20. Konstytucji Rzeczypospolitej Polskiej stanowi, że państwo będzie zapewniało rozwój społecznej gospodarce rynkowej, której warunki uwzględniają również spółdzielczośćc ${ }^{21}$.

Prawo spółdzielcze zostało znowelizowane 7 lipca 1994 roku. Zachowane zostały m.in. demokratyczne zasady wyboru organów i niezależność spółdzielni. Jednym ze społecznych celów ruchu spółdzielczego powinno być przestrzeganie zasady apolityczności ${ }^{22}$.

Spółdzielnia jest osobą prawną $\mathrm{w}$ rozumieniu prawa cywilnego. Podatek dochodowy jest płacony państwu równorzędnie od spółdzielni i pozostałych rodzajów przedsiębiorstw. Spółdzielnie płaciły podwójne opodatkowanie dochodów ${ }^{23}$. Ze względu na warunki członkowie spółdzielni rolniczych decydowali się na zmiany, które by pozwoliły im na funkcjonowanie w warunkach gospodarki rynkowej. W wielu przypadkach konsekwencje nie były zgodne z zamierzeniami. $\mathrm{W}$ wielu spółdzielniach rolniczych nastąpiło zmniejszanie się liczby członków, wskutek czego zaczęli dominować członkowie-pracownicy. Posunięciem, na które mieli wpływ członkowie-pracownicy w większości spółdzielni było podniesienie udziałów członkowskich. Rolnicy rezygnując ze swojego członkostwa podawali to jako główny powód $(45 \%)^{24}$. Wysoki udział członkowski był przeszkodą do wstępowania do spółdzielni ludności o niewielkich przychodach, czyli tej warstwy, do której głównie była skierowana idea spółdzielczości. Stwierdzenie Stanisława Wojciechowskiego jest aktualne i traktowane jako jeden $\mathrm{z}$ głównych celów wspólnej polityki rolnej Unii Europejskiej: „(...) poza kooperacją spożywców najbardziej intensywny i wszechstronny rozwój spółdzielni spotykamy w rolnictwie, (...) Potrzebę ich wszędzie potęguje postęp techniki rolniczej, stosowanie nawozów sztucznych, maszyn, specjalizacja w hodowli zwierząt, warzyw, nasion. Przemysł ugania się za ilością, w rolnictwie jakość produktów gra coraz większą rolę i to jeszcze bardziej potęguje potrzebę łączenia się dla sprostania wymaganiom rynku. Kooperacja w rolnictwie stała się nietylko znakomitym środkiem utrzymania i wzmocnienia gospodarstw chłopskich, ale wprost nieodzownym warunkiem dalszego postępu, przekształcenia gospodarczych i kulturalnych warunków bytu ludności wiejskiej. Szczególne znamienne jest wkraczanie

${ }_{21}$ Konstytucja Rzeczypospolitej Polskiej z komentarzem, Warszawa 1997, s. 43. Dz. U. 1997 Nr 78 poz. 483.

22 M. G. BRoDZIŃsKI, Zalożenia strategii rozwoju spóldzielczości w latach 2000-2005, Warszawa 1999, s. 5.

23 Podwójne opodatkowanie, gdyż był obowiązek odprowadzania podatku dochodowego od zysku spółdzielni i podatku dochodowego płaconego przez członków spółdzielni od dywidendy. Przed akcesją w spółdzielniach rolniczych prowadzących działy specjalne (chów brojlerów, brygady remontowe, ślusarnie) obowiązywał podatek dochodowy od osób prawnych, który był płacony zgodnie z zasadami księgowości. M. G. BRodziński, Założenia strategii rozwoju..., Warszawa 1999, s. 48-50.

24 M. G. BRodziński, Dylematy rozwoju spółdzielczości w Polsce, Warszawa 1999, s. 144. 
spółdzielni w indywidualne gospodarstwa członków, poddawanie ich spólnemu planowi gospodarczemu w hodowli i żywieniu inwentarza oraz przygotowywaniu jednorodnych produktów, odpowiadających wymaganiom spożywców. Tej różnorodnej działalności gospodarczej towarzyszy organizowanie rozmaitych spółdzielni dla podniesienia kultury, oświaty zawodowej oraz innych ułatwień i zabezpieczania owoców pracy". Wojciechowski wyznaczył cele spółdzielczości $\mathrm{w}$ warunkach prac nad zintegrowaniem byłych zaborów i rozwojem państwa polskiego po odzyskaniu niepodległości. Sytuację społeczną i gospodarczą w Polsce w okresie transformacji ustrojowej dla przedstawicieli wielu grup społecznych można porównać $\mathrm{z}$ warunkami i problemami, które musieli pokonać obywatele II Rzeczypospolitej, by odbudować państwo polskie.

Po zmianie ustroju w Polsce poważnym problemem dla rolników do powoływania spółdzielni były brak wzajemnego zaufania i motywacji do organizowania się spowodowane m.in. zahamowaniem rozwoju rolnictwa wskutek nagłego, bardzo wysokiego podniesienia oprocentowania kredytów, co doprowadziło do upadku wielu istniejących spółdzielni i uniemożliwiło powoływanie nowych. Drugim negatywnym czynnikiem dla rozwoju spółdzielczości było przejmowanie majątku spółdzielni przez dotychczasowe zarządy. Te czynniki miały znaczący wpływ na zniechęcenie rolników do organizowania się ${ }^{25}$. „Wieś polska nie wierzy w przyszłość, bo straciła swoją przeszłość. Nie zna ani swoich, ani cudzych doświadczeń, które mogłaby wykorzystać. „Normalnością” został miniony system"26. Pomyślną przyszłość rozwoju polskiego rolnictwa mogą zapewnić absolwenci akademii rolniczych.

Przyczyny, które spowodowały, że rolnicy niechętnie organizują się i ich konsekwencje są widoczne także $\mathrm{w}$ dzisiejszych warunkach, były związane $\mathrm{z}$ wprowadzaniem $w$ ustroju socjalistycznym reguł gospodarki planowej i kolektywizacji: »"Spółdzielczość", z którą w Polsce mamy do czynienia, często nawet nie wie, że nie jest spółdzielczością. Albo w ogóle jej nie ma. Zwłaszcza tej najważniejszej dla wsi - zaopatrzenia i zbytu ${ }^{27}$.

W okresie transformacji ustroju zmieniła się struktura organizacji rolniczych. Spółdzielnie rolnicze, w których uczestniczyli kilkaset członków nie mogą utrzymać się w obecnych warunkach. Rolnicy dostarczający na rynek znaczne partie płodów i produktów rolnych organizują się w grupy producenckie lub inne formy organizacji.

25 Zainteresowanych czytelników autorka odsyła do: Zdanie odrębne sędziego TK Biruty Lewaszkiewicz-Petrykowskiej do wyroku Trybunału Konstytucyjnego z dnia 24 października 24 października 2000 r. Sygn. SK 7/00. Dz. U. $2000 \mathrm{Nr} 92$ poz. 1024; wyrok z dnia 24 października 2000 r. Sygn. SK $7 / 00$.

26 S. BRATKOWSKI, Zamiast krakać, czyli to wieś ma przyszłość. Strona z dnia 8 maja 2007, http:// www.fcp.edu.pl/site2/bibl/b019.html.

27 Komentarz S. Bratkowskiego dostępny na stronie internetowej. S. BRATKOwSKI, Zamiast krakać, czyli to wieś ma przyszłość. Strona z dnia 8 maja 2007, http://www.fcp.edu.pl/site2/bibl/b019.html. 
Spółdzielcy wysunęli postulat, że należy zrównać poziom ich opodatkowania do wysokości podatku osób fizycznych prowadzących działalność gospodarczą ${ }^{28}$.

Rząd powinien uwzględnić w swojej polityce przeprowadzanie akcji zachęcającej rolników do zrzeszania się np. w formie ulg finansowych, korzystanie z doświadczeń rolników w formie szkoleń w innych krajach etc.

Jan XXIII zachęcał rolników, aby zrzeszali się w spółdzielniach, gdyż „ułatwiają one rolnikowi korzystanie z postępów nauki i techniki i walczą o właściwe kształtowanie się cen płodów rolnych"29.

Bieżąca informacja jest ważnym czynnikiem ułatwiającym rolnikom podejmowanie decyzji w celu wprowadzania zmian $w$ ich gospodarstwie. Zaufanie rolników do Unii Europejskiej jest trzykrotnie niższe niż innych grup społecznych ${ }^{30}$.

\section{Porównanie warunków spółdzielczości w Polsce i innych krajach Unii Europejskiej}

Poniżej zostały zwięźle przedstawione możliwości funkcjonowania spółdzielni w innych krajach Unii Europejskiej.

W prawie Unii Europejskiej spółdzielnie są wymienione w Traktacie Rzymskim w „Prawie przedsiębiorczości” jako jeden z rodzajów „spółek” ${ }^{31}$.

W UE spółdzielnie działające $w$ branży rolniczej są traktowane $w$ sposób szczególny.

W drugiej połowie lat dziewięćdziesiątych XX wieku udział spółdzielni w rynku rolnym wynosił $83 \%$ w Holandii, $79 \%$ w Finlandii i 55\% we Włoszech. W leśnictwie spółdzielnie miały $60 \%$ udziału w rynku w Szwecji i $31 \%$ w Finlandii. W sektorze usługowym spółdzielnie miały przeszło $50 \%$ udziałów w rynku bankowości we Francji, 35\% w Finlandii, 31\% w Austrii i 21\% w Niemczech ${ }^{32}$.

Jeśli spółdzielnie integrują się w łańcuchu produkcyjnym żywności lub pracują nad nowymi produktami, potrzebują do tego celu kapitału. W krajach Unii Europejskiej, aby to umożliwić stosowane są zmiany w statutach spółdzielni, by dopuścić do spółdzielni inwestorów z zewnątrz. We Francji tylko rolnicy mogą być członkami spółdzielni, zasiadać w ich Radach Nadzorczych. Możliwość dokonania obrotu ze spółdzielnią przysługuje wyłącznie rolnikom. Realizacja zadań

28 M. G. BRodzIŃski, Założenia strategii rozwoju spóldzielczości w latach 2000-2005. Warszawa 1999, s. 10.

29 Slownik katolickiej nauki spolecznej. red. nauk. Władysław Piwowarski, Warszawa 1993, s. 171.

${ }^{30}$ B. FedYSZAK-RADZIEjowsKa: Nowe elity i nowe organizacje lokalne wobec "starych" problemów polskiej wsi. Wieś i Rolnictwo. Suplement do nr 3 2003, s. 54.

31 Traktat Rzymski 25 marca 1957, rozdział 2 „Prawo przedsiębiorczości”, artykuł 58.

32 Na podstawie: „Bialej Księgi o przedsiębiorstwach spótdzielczych”, Bruksela 2001. 
spółdzielni jest wyznaczona w statucie. Jeśli rolnicy decydują, że dokonają obrotu $z$ osobą prawną z zewnątrz, to może on wynosić najwyżej $20 \%$ przychodu spółdzielni ${ }^{33}$. Ilość udziałów w spółdzielni wyznacza zakres praw jej członków. Jeśli w statucie spółdzielni została zapisana zasada „ważenia głosów”, rolnikowi, który dokonał największych obrotów ze spółdzielnią, są przyznawane maksymalnie dwadzieścia głosów. Tym samym jego głos jest ważniejszy w podejmowaniu decyzji na zebraniach spółdzielczych. Inwestorzy niebędący członkami spółdzielni mogą posiadać najwięcej 20\% głosów na Walnym Zgromadzeniu i 30\% w Radzie Nadzorczej. Spółdzielnie są zwolnione z podatku dochodowego. We Francji wprowadzono udziałowe papiery pożyczkowe, ale ich posiadaczowi nie przysługuje prawo głosu. Inwestor ma prawo do udziału w wynikach ekonomicznych projektu, w którym uczestniczy. Nie ma obowiązku bezpośredniego zarządzania firmą. Ponosi ryzyko, ale sukces jest większy niż przy zwykłym kapitale pożyczkowym $^{34}$.

Propozycja, by większy majątkowy udział członka w spółdzielni oznaczał większy wpływ na decyzje gospodarcze jest typowa dla spółek, sprzeczna z podstawowymi założeniami spółdzielczości ${ }^{35}$.

Autorka uważa, że kwestia przekształcenia się spółdzielni w spółkę prawa handlowego powinna być zgodna z prawem i wolą członków spółdzielni ${ }^{36}$.

${ }^{33}$ Wyjątek stanowi SICA.

34 Krytycznie ocenia model spółdzielni opartej na wzorcu francuskim M. Ławrynowicz, który stwierdza, że problemy „(...) narastają wraz z wielkością spółdzielni, coraz większą rozbieżnością interesów i rosnącymi potencjalnie zyskami z działalności. Spółdzielnie, w których nie realizuje się interesów grup lub czlonków, borykać się będą ze słabszą partycypacją i niską identyfikacją udziałowców, trudniej w nich o niezbędną informację i o członków zainteresowanych strategicznymi kwestiami. (...) Źle zdefiniowane prawa własności wpływają na motywację członków do inwestycji i zdolności do zwiększania kapitału organizacji. Członkowie są bardziej skłonni inwestować wtedy, gdy spółdzielnia charakteryzuje się zamkniętym członkowstwem, transferowalnymi i wycenianymi udziałami, co powoduje minimalizację podstawowych problemów spółdzielni - jazdy na gapę, portfela i horyzontu". Zainteresowanych czytelników autorka odsyła do np.: M. Syкuta, M. L . Cook, A New Instytutional Econoimcs Approach to Contracts and Cooperatives. American Journal of Agricultural Economics. 5 2001, s. 5. Na podstawie: M. Ławrynowicz: Spółdzielnia a koncepcje neoinstytucjonalne. Ruch Prawniczy, Ekonomiczny i Socjologiczny z. 3 2004, s. 159-179.

Czytelników zainteresowanych tematyką związaną ze spółdzielczością rolniczą we Francji autorka odsyła np. do: D. MIERzwa, Funkcjonowanie przedsiębiorstw spóldzielczych w świetle prawa. (Analiza porównawcza Francji i Polski). Zagadnienia Ekonomiki Rolniczej 12003 s. 22-27; D. Mierzwa: Opcje strategiczne spółdzielni rolniczych w krajach UE. Postępy Nauk Rolniczych $w$ krajach UE 12002 s. 115-122.

35 Zgodnie $z$ art. $36 \$ 3$, ustawy o prawie spółdzielczym z dnia 16 września 1982 roku, Dz.U. $\mathrm{Nr}$ 188 poz. 1848.

36 Z uwzględnieniem uwag Edwarda Taylora, że: „Każda z tych instytucji wymaga (...) odmiennych metod działania, innych pól pracy (...). I nic niema jałowszego, bardziej bezcelowego i zawodnego, jak stosowanie jednych instytucyi tam, gdzie trzebaby właśnie drugich, do celów 
Możliwość wyboru wpłynie, że obywatele będą bardziej chętnie podejmowali działalność gospodarczą, na czym może zyskać skarb państwa.

Rozwiązanie dotyczące udziałów inwestycyjnych zostało zapisane w 1990 roku w fińskim prawie spółdzielczym.

Specjaliści zajmujący się spółdzielniami wskazują, że regulacje państwa w tych relacjach są konieczne, gdyż występuje konflikt między interesem producenta, który wymaga tak wysokich cen na swoje produkty, jak to tylko jest możliwe, a interesem inwestora, który $z$ kolei szuka jak najwyższego zysku od zainwestowanego kapitału w postaci udziałów w przedsiębiorstwie. W UE jest uważane za nowe zjawisko i nie przeprowadzono badań $\mathrm{z}$ tego zakresu ${ }^{37}$. W ostatnich latach $\mathrm{w}$ Unii Europejskiej liczba spółdzielni rolniczych zmniejszyła się, lecz wzrosły ich obroty.

W Polsce cele ideowe spółdzielni w większości przekładają się na dążenia, jakie obecnie zakładają sobie rolnicy zrzeszeni w grupach producentów ${ }^{38}$. Najważniejszym celem, dla którego powstawały spółdzielnie na wsiach było wyeliminowanie pośredników i przejęcie przez chłopów zbytu i przetwórstwa płodów rolnych. Bratkowski podsumował politykę rządów z zakresu rozwoju przedsiębiorczości wiejskiej prowadzoną w okresie transformacji ustrojowej: „(...) nikt nie wzywa chłopów do odbudowy spółdzielczości, do udziału w prywatyzacji państwowych zakładów przemysłu, który przetwarza płody rolne, ani do udziału w prywatyzacji zakładów, które te płody gromadzą i przechowują, jak Państwowe Zakłady Zbożowe. Nikt nie organizuje polskich rolników, ani w skali lokalnej, ani w skali ogólnokrajowej, do wspólnego zakupu - na kredyt! - udziałów w tych przedsiębiorstwach. Nikt nie występuje o to, by np. rolnikom - dostawcom tych zakładów przekazywać, w zależności od wielkości dostaw i ich jakości, kolejne porcje udziałów. Od lat w różnych krajach świata producenci rolni przejmowali role właścicieli przemysłu, który pracował na ich surowcu. W cukrownictwie, w produkcji win i w innym przetwórstwie. To nie „pomysł”. To rutyna. (...) Dziś blisko dwie trzecie ceny detalicznej przetworów mlecznych idzie do kieszeni pośredników, tj. właścicieli mleczarni oraz ich partnerów od transportu i handlu"39.

i zadań zupełnie im nie odpowiadających, (...) W tych warunkach musi życie przynieść niepowodzenia, (...) tam nawet, gdzie celowa i właściwa organizacya dałaby wielkie i owocne pole dla pracy tak jednych jak i drugich instytucyi, każdej we właściwym zakresie działania". E. Taylor: Pojęcie współdzielczości, Warszawa 1916, s. 131.

37 M. G. BRodzińskı, Dylematy rozwoju..., Warszawa 1999, s. 204-205.

${ }^{38}$ Typy organizacji, w jakich rolnicy mogą obecnie kooperować: spółdzielnia, spółka handlowa, zrzeszenie, stowarzyszenie. Patrz też: „Organizacja i funkcjonowanie grup producentów rolnych". WODR Warszawa 2002.

39 S. BRATKowsKi, Zamiast krakać, czyli to wieś ma przyszłość. Strona z dnia 8 maja 2007. http:// www.fcp.edu.pl/site2/bibl/b019.html.; sprawa organizacji przedsiębiorczości wiejskiej była poruszana $m$. in. na łamach „Buntu Młodych Duchem” przez Henryka Makowskiego: „(...) rozpocznijmy upowszechnianie budowy SILOSÓW zbożowych w gospodarstwach; uniezależni to rolników od lichwiarskich cen i koniecznych sprzedaży. Zacznijmy od silosów, potem upo- 
Spółdzielnia jest zrzeszeniem osób, w przeciwieństwie do spółki handlowej, która jest zrzeszeniem kapitałów. Spółdzielnia, jak każda korporacja, stawia sobie za cel realizację określonych wspólnych zadań przez osoby dobrowolnie zrzeszone na zasadach, które każdy członek uznał za korzystne dla siebie. Według prawa polskiego głos każdego członka spółdzielni jest równy. Potrzeba kapitałów inwestycyjnych jest dylematem nie tylko spółdzielni w Polsce. Tanie kredyty umożliwilyby powstawanie nowych form współpracy gospodarczej takich jak grupy producentów. W krajach Unii Europejskiej pomocy inwestycyjnej udzielają związki zawodowe (np. we Francji, Irlandii) i państwowe lub municypalne agencje rozwoju przedsiębiorczości (np. w Wielkiej Brytanii) ${ }^{40}$.

W Norwegii w 1981 roku został powołany na miejsce poprzedniego związku Oddział do Spraw Rozwoju Spółdzielczego, który został przyłączony do norweskiego związku farmerów. Nadal jest organem reprezentującym interesy spółdzielni rolniczych i przez nie finansowany. O silnej pozycji tej formy działalności społeczno-gospodarczej w Norwegii świadczy istnienie grupy spółdzielni kredytowych, bankowych i ubezpieczeniowych ${ }^{41}$.

Rząd hiszpański udziela pomocy spółdzielniom i grupom producentów przyznając pięcioletnie subsydia na rozwój przetwórstwa i marketingu, subsydia do zakupu maszyn przez stowarzyszenia producentów rolnych i dla stowarzyszeń, które podejmują działalność marketingową. Przedsiębiorstwa spółdzielcze są zwalnianie z podatków, także państwo kompensuje nowo przystępującym członkom koszty, które wnoszą do spółdzielni ${ }^{42}$. Obowiązująca od 1998 roku ustawa o umowach produkcyjnych ${ }^{43}$ dała głównie organizacjom rolniczym angażującym się w produkcję, przetwórstwo i handel podstawy prawne i środki finansowe do działania we wspólnym interesie w celu poprawienia wydajności w całym sek-

rządkowanie sprawy marż handlowych, organizowanie sprzedaży poprzez SPÓŁDZIELNIE, prawdziwe spółdzielnie rolnicze, rolników. Dotychczasowa forma sprzedaży produktów rolnych delikatnie ujmując jest zupełnie przypadkowa i nie gwarantująca zapłaty za towar (należność otrzymuje się $z$ reguły po miesiącu lub dwóch miesiącach). Ten bałagan trwa od lat piętnastu, pomimo że bywali już ministrowie z różnych kolorów. H. Makowskı, Komu bije dzwon i dlaczego. Bunt Młodych Duchem 52004 s. 28.

40 S. DY KA, Dylematy spóldzielczości rolniczej w okresie transformacji systemowej, (W:) Spółdzielczość rolnicza w gospodarce rynkowej (doświadczenia i przyszłość), red. nauk. Eugeniusza Pudełkiewicza, Zbigniewa T. Wierzbickiego, Warszawa 1993, s. 103. [Materiały Międzynarodowego Sympozjum „Doświadczenia i przyszłość spółdzielni rolniczej w gospodarce rynkowej", Miedzeszyn k. Warszawy, 17-19 lutego 1993 r.].

${ }^{41}$ K. Krzyżanowska, Przedsiębiorczość zespołowa rolników i jej uwarunkowania, Warszawa 2003, s. 58.

42 Ibidem, s. 66.

43 Przyjęta również w 1998 roku Ustawa o organizacjach międzyzawodowych spełnia wymagania UE dotyczące funkcjonowania tych organizacji z zachowaniem przepisów o konkurencji. K. Krzyżanowska ss. 67. 
torze rolno-spożywczym. Spółdzielnie i zrzeszenia rolnicze umocniła konsekwentnie stosowana zasada, że wartość produkcji grupy podmiotów wyznacza ich znaczenie $w$ organizacji ${ }^{44}$. Modernizacja prywatnych zakładów przetwórstwa mięsa i produktów mleczarskich na terenach priorytetowych jest prowadzona $\mathrm{z}$ udziałem środków budżetowych ${ }^{45}$.

W Niemczech postawiono na integrację pionową między rolnictwem a przemysłem, której celem jest zmniejszenie interwencji państwa. Władze federalne wspomagają organizacje producentów i spółdzielnie zajmujące się marketingiem i przetwórstwem poprzez udzielanie corocznych dotacji przez pięć lat funkcjonowania i pomocy inwestycyjnej w formie subsydiowanego kredytu przez siedem lat ${ }^{46}$.

W krajach dotychczasowej „piętnastki” UE producenci wspólnie podejmują potrzebne im działania ${ }^{47}$. W Unii Europejskiej nie każda organizacja producencka jest uważana za „organizację producentów”, a tylko taka może uzyskać wsparcie finansowe Unii ${ }^{48}$. Przyznane pieniądze są przeznaczane na działania do osiągnięcia celów wyznaczonych przez grupę. Producenci zrzeszający się w nowej organizacji mogą uzyskać pomoc, jeśli ich organizacja wcześniej uzyska status wstępnego uznania ${ }^{49}$. Pomoc finansowa musi być zgodna $\mathrm{z}$ wyznaczoną polityką UE i dlatego musi się znajdować pod kontrolą Unii.

W Stanach Zjednoczonych Ameryki Północnej organizacje rolnicze będące odpowiednikiem unijnych grup producentów uzyskują subwencję z funduszów ogólnokrajowych.

Spółdzielnie są dobrze reprezentowane w Brukseli przez ponadnarodowe organizacje rolnicze reprezentujące różne grupy interesów. Indywidualni producenci rolni mogą zrzeszać się w Komitecie Rolniczych Organizacji Zawodowych (COPA). KROZ ma największy wpływ spośród organizacji rolniczych na wspólną politykę rolną ${ }^{50}$.

44 Ibidem, s. 67,

45 Ibidem, s. 66,

46 Ibidem, s. 68,

47 W roku 1996 podczas Kongresu Międzynarodowego Związku Spółdzielczego zmieniono międzynarodowe zasady spółdzielcze. Została przyjęta bardziej liberalna definicja spółdzielni: „Spółdzielnia jest autonomicznym stowarzyszeniem osób, które zrzeszyły się z własnej woli, w celu zaspokojenia ich wspólnych ekonomicznych, społecznych oraz kulturalnych dążeń i aspiracji przez przedsiębiorstwo, którego są właścicielami i którym wspólnie zarządzają".

48 Zgodnie z Rozporządzeniem Rady (EC) 2200/96 w sprawie wspólnej organizacji rynku owoców i warzyw, zostały wprowadzone pozostałe glówne akty regulujące rynek owoców i warzyw: Rozporządzenie Komisji 411/97/EC, Rozporządzenie Komisji 412/97/EC, Rozporządzenie Komisji 478/97/EC, Rozporządzenie Komisji 659/97/EC, Rozporządzenie Komisji 20/98/EC, Rozporządzenie Komisji 1647/98/EC, Rozporządzenie Rady 2201/96, Rozporządzenie Komisji 504/97/EC, Rozporządzenie Rady (UE) 2699/2000.

49 K. KrzyżanowsKa, Przedsiębiorczość zespolowa rolników i jej uwarunkowania, Warszawa 2003, s. 51.

${ }^{50}$ Z. Gumkowsk, Organizacje rolnicze w Unii Europejskiej, Warszawa 2002, s. 9. 
Członkami Głównego Komitetu Spółdzielczości Rolniczej (COGECA) są producenci spółdzielczy, producenci żywności są zrzeszeni w Konfederacji Przemysłów Żywnościowych i Napojów, handlowcy w Europejskim Komitecie do spraw Handlu Artykułami Rolno-Spożywczymi (CELCA) i EUROCOMMERCE $^{51}$.

\section{Spółdzielczość wiejska możliwością rozwoju gospodarstw rolnych i rozwoju lokalnego}

Od 1 maja 2004 roku zmieniły się zasady funkcjonowania rolnictwa. Dotychczasowy system interwencji na rynkach rolnych został zastąpiony rozwiązaniami stosowanymi w Unii Europejskiej. Wprowadzono system płatności bezpośrednich, który obejmuje wszystkich rolników ${ }^{52}$. Utrzymane zostaną wiele $\mathrm{z}$ dotychczasowych instrumentów $w^{53}$.

Po integracji Polski z Unią Europejską Agencja Restrukturyzacji i Modernizacji Rolnictwa oraz Agencja Rynku Rolnego pełnią funkcje agencji płatniczych ${ }^{54}$. System interwencji na podstawowych rynkach, zgodny z przepisami Unii Europejskiej prowadzić będzie Agencja Rynku Rolnego. Wsparcie gospodarstw rolnych realizowane przez Agencję Restrukturyzacji i Modernizacji Rolnictwa obejmuje kilka obszarów: płatności bezpośrednie, SAPRAD, Plan Rozwoju Obszarów Wiejskich, Sektorowy Program Operacyjny „Restrukturyzacja i modernizacja sektora żywnościowego oraz rozwój obszarów wiejskich", kredyty o obniżonej stopie oprocentowania, poręczenia i gwarancje kredytowe, dotacje.

Rolnicy są grupą inicjatywną, która dąży do podniesienia poziomu rozwoju swojego regionu. W okresie ustroju socjalistycznego społeczna inicjatywa mieszkańców wsi uwidaczniała się w zaangażowaniu w przedsięwzięcia, które wpływały na jakość życia i rozwój lokalny: pomoc w konserwacji i modernizacji

51 Ponadto Europejskie Centrum Ksztalcenia Środowisk Rolniczych (CEPFAR) i Europejska Konfederacja Rolnictwa (CEA). Ibidem s. 9-11.

52 W sprawie dotacji na rozwój obszarów wiejskich ze środków unijnych swoje stanowisko przedstawiła Krajowa Rada Spółdzielczości. Stwierdzila, że strategia rozwoju obszarów wiejskich przyjęta na szczycie w Kopenhadze, na którą przyznano pięć miliardów sto milionów euro w latach 2004-2006 nie uwzględnia zakładania nowych spółdzielni działających $w$ rolnictwie i jego otoczeniu. Krajowa Rada Spółdzielcza. Strona z dnia 9 maja 2007. www.krs.com.pl/home.php

53 Np. kredyty o obniżonej stopie oprocentowania na zakup środków do produkcji rolnej oraz na inwestycje Oprocentowanie kredytów inwestycyjnych udzielonych w latach poprzednich objętych dopłatami ARiMR od 26. 08.2004. (W:) Biuletyn Informacyjny MRiRW 102004 s. 38-39, Oprocentowanie kredytów inwestycyjnych udzielonych przez Banki objętych doplatami ARiMR od 26. 08.2004 (W:) Biuletyn Informacyjny. MRiRW, 102004 s. 39.

54 Agencja Rynku Rolnego. Strona $z$ dnia 9 maja 2007. www.arr.gov.pl/index.php?dDzialu$=00257$. 
infrastruktury technicznej np. naprawa i budowa lokalnych dróg, budowa szkół i ośrodków np. kulturalno-oświatowych. Badania przeprowadzone w 2002 roku potwierdziły, że skłonność rolników do współdziałania z innymi w pracy społecznej jest zdecydowanie wyższa niż w innych grupach społecznych ${ }^{55}$.

Rolnicy są zainteresowani trafną produkcją. W tym celu spółdzielnie mogłyby ustalać z odbiorcą towar, zająć się sprawami logistyki ${ }^{56}$. Celowe byłoby tworzenie baz danych, które zawierałyby informacje przydatne w działalności rolniczej ${ }^{57}$.

Rozwiązania wspomagające postęp społeczny i rozwój gospodarczy wskazał Jan XXIII: „(...) tego rodzaju warsztaty [rzemieślnicze] i przedsiębiorstwa [rolnicze] będą rzeczywiście żywotne i kwitnące wtedy, jeśli będą się ustawicznie dostosowywać - w zakresie narzędzi i metod produkcji - do warunków aktualnych, te zaś określają zarówno postępy nauki i techniki, jak i zmieniające się z dnia na dzień potrzeby i gusty ludności. Winni o to dbać sami rzemieślnicy i spółdzielcy" ${ }^{58}$.

Doradcy z Ośrodków Doradztwa Rolniczego, pracownicy samorządów znając możliwości mogliby podawać propozycje, które mogą służyć pomocą w rozwiązywaniu spraw w terenie: „Polscy rolnicy, wbrew teoriom na temat ich niechęci do innowacji, potrafią nawet radykalnie zmienić strukturę i zasiewów, i hodowli. Reagują na zmiany rynkowe inteligentnie i szybko - byle o nich wiedzieli. (...)

55 Natomiast rolnicy są grupą niechętnie podejmującą działalność gospodarczą z osobami spoza swojej rodziny. Instytucją, którą darzą zaufaniem częściej niż inne grupy społeczno-zawodowe są władze lokalne. B. FedyszaK-RADzIEjowsKa: Nowe elity $i$ nowe organizacje lokalne wobec „starych" problemów polskiej wsi. (W:) Wieś i Rolnictwo. Suplement 32003 s. 54.

${ }^{56}$ Logistyką $\mathrm{w}$ odniesieniu do rolnictwa jest zintegrowany system sprzedaży płodów rolnych $\mathrm{i}$ informacyjne uwarunkowania, których zadaniem są najkorzystniejsze relacje między usługami spółdzielni a związanymi z tym kosztami. P. BLAIK, Logistyka a efektywność w skali mikroekonomicznej. Handel Wewnętrzny 4-5 1992 s. 19-23.

57 Takie jak interpretacje przepisów prawnych odnośnie określonej działalności gospodarczej, np. grup producentów, rachunkowość rolnicza, kalkulacje kosztów, rozliczenia podatkowe, możliwości współpracy w handlu w warunkach Unii Europejskiej. Komentując obecny stan rozwoju spółdzielczości i innych form współpracy rolników Stefan Bratkowski wskazal, że: „Chodzi o związki, lokalne lub nawet międzywojewódzkie, ze wspólnym fachowym doradztwem i opieką weterynaryjną. $Z$ wymianą doświadczeń i rozpowszechnianiem materiałów szkoleniowych - jak w dawnych kółkach rolniczych Wielkopolski. (...) Dzisiejsze „kółka rolnicze” nie mają nic wspólnego z prawdziwymi dawnymi polskimi kółkami rolniczymi. Kółka rolnicze nie były żadną organizacją związkową ani polityczną. Organizowały wzajemną pomoc rolników i samokształcenie zawodowe. Był to oryginalny polski wynalazek; kółka rolnicze odegrały olbrzymią rolę w samoobronie wsi polskiej pod zaborem pruskim. (...) Dawne kółka kipiały od aktywności: sprowadzały bydło zarodowe, nioski o wielkiej wydajności, kwalifikowane ziarno, maszyny. Ich członkowie razem uczyli się wszystkiego, co rolnicy powinni wiedzieć. Dzisiejsze "kółka” są kpiną ze starej, porządnej nazwy". S. BRATKowsKI, Zamiast krakać, czyli to wieś ma przyszłość. Strona $z$ dnia 9 maja 2007. http://www.fcp.edu.pl/site2/bibl/b019.html

58 JAN XXIII, Mater et magistra..., s. 36-37. 
Niestety, nikt na użytek rolników nie bada rynku i nie mówi im, jakie są perspektywy zbytu na następny rok"s9.

$\mathrm{W}$ państwach o wysokim poziomie rozwoju gospodarczego tworzenie przez spółdzielczość miejsc pracy jest traktowane jako znaczące odciążenie budżetu państwa ${ }^{60}$. Polityka $w$ dziedzinie spraw społecznych UE zakłada m.in. promocję zatrudnienia. W obecnej sytuacji rynku pracy możliwości rozpoczęcia praktyki zawodowej przez absolwentów są ograniczone ${ }^{61}$.

W Polsce problemem jest brak ustawy o spółdzielniach socjalnych, które dawałyby możliwość zmniejszenia problemu bezrobocia absolwentów, niepełnosprawnych lub mających problem ze znalezieniem pracy z innych względów.

Działalność gospodarcza, która przynosi dochód, wymaga od przedsiębiorców kapitału, doświadczenia zawodowego, czyli warunków, których nie mogą spełnić absolwenci. „Jeśli natomiast chodzi o wniesienie korektyw, ulepszeń do funkcyonowania naszego ustroju społecznego w pewnych dziedzinach życia, trwałe złagodzenie jego braków i ujemnych stron, stałą poprawę położenia słabszych gospodarczo, jako takich, - tam miejsce dla stowarzyszenia współdzielczego. Pierwsze, można by powiedzieć, ułatwiają podnoszenie się, wybijanie jednostek, grup gospodarczych, przemieniając je na czynne w stosunku do ustroju kapitalistycznego społeczeństwa, wyciągają je doń z pożytkiem dla nich, utrwalając tem samem ów ustrój, tak jak on istnieje, - drugie ulepszają funkcyonowanie ustroju gospodarczego, zmniejszają tarcia społeczne, polepszają położenie warstw słabszych bez względu na dane jednostki, w skład ich w danej chwili wchodzące"62.

59 S. BRATKowski, Zamiast krakać, czyli to wieś ma przyszłość. Strona z dnia 9 maja 2007. http:// www.fcp.edu.pl/site2/bibl/b019.html.

60 M. A. SchaARs, Spółdzielczość, zasady i praktyka. b.m. wyd. 1991 s. 81.

${ }_{61}$ Nowe szanse podjęcia pracy przez absolwentów zostały uregulowane w Ustawie z dnia 24 kwietnia 2003 roku. - Przepisy wprowadzające ustawę o działalności pożytku publicznego i o wolontariacie. W ustawie $z$ dnia 26 lipca 1991 roku o podatku dochodowym od osób fizycznych (Dz. U. z 2000 r. Nr 14, poz. 176, z późn. zm.) wprowadzono zmiany i ustalono w artykule $21 \mathrm{w}$ ust. $1 \mathrm{w}$ pkt. 113, że „przychody wolontariuszy otrzymane od organizacji pozarządowych, podmiotów, organów administracji publicznej oraz jednostek organizacyjnych, o których mowa w art. 42 ust. 1 ustawy $z$ dnia 24 kwietnia 2003 r. o działalności pożytku publicznego i o wolontariacie (Dz. U. Nr 96, poz. 873), z tytułu kosztów szkoleń, podróży służbowej, diet, badań lekarskich, wyposażenia w środki ochrony osobistej, składki opłaconej zgodnie z przepisami o powszechnym ubezpieczeniu zdrowotnym oraz ubezpieczeniu od następstw nieszczęśliwych wypadków opłacanych na zasadach określonych w odrębnych przepisach". Wolontariat jest możliwością ograniczenia bezrobocia wśród absolwentów szkół wyższych, ale nie zapewnia młodemu człowiekowi dochodów i nabycia praktyki zawodowej. Ustawa z dnia 27 kwietnia 2006 r. o spółdzielniach socjalnych. Dz.U.2006 Nr 94 poz. 651.

62 E. TAYLOR, Pojęcie współdzielczości. Warszawa 1916 s. 131. 
Obecnie są powoływane organizacje społeczne, których przesłaniem jest działalność na rzecz powstania „autentycznej spółdzielczości”63.

Państwo powinno umożliwiać powstawanie inicjatyw, które zaspokajają potrzeby społeczne w terenie. Aby pobudzić współpracę wspólnot lokalnych potrzebne jest obywatelskie zaangażowanie oparte na wzajemnym współdziałaniu. $\mathrm{Z}$ nieformalnych norm współpracy i zaufania składa się pojęcie kapitału społecznego ${ }^{64}$.

Poziom bezrobocia na polskiej wsi jest szacowany obecnie na około dwa miliony osób ${ }^{65}$. Powstawanie spółdzielni może przyczynić się do zmniejszenia bezrobocia. Komisja Europejska wytypowała siedemnaście dziedzin, w których najtrafniej można tworzyć nowe miejsca pracy ${ }^{66}$. Badania potwierdziły, że podjęta działalność jest prowadzona w dużym stopniu i skutecznie przez formy spółdzielcze ${ }^{67}$. Ważną rolę powinni odegrać przedstawiciele samorządu np. radni, którzy znają problemy istniejące $w$ terenie.

Spółdzielnie rolnicze płacą obligatoryjnie składki na Fundusz Pracy, który zostal utworzony w 1989 roku. Dysponentem Funduszu Pracy jest od kwietnia 2002 roku Ministerstwo Pracy i Polityki Społecznej. Fundusz nie ma osobowości prawnej, działa na bazie składek i dotacji budżetowych. Służy finansowaniu m.in. kosztów szkolenia pracowników68.

Rolę spółdzielni w celu zapewnienia poziomu życia docenił Jan XXIII w „Mater et magistra”: „(..) z tego powodu chcemy wyrazić uznanie dla zasług tych Naszych synów, którzy działając we wszystkich krajach czy to zrzeszeniach spółdzielczych, czy też $w$ różnego rodzaju stowarzyszeniach, dążą niestrudzenie do zapewnienia rolnikom w każdym ustroju społecznym nie tylko należnej im obfitości dóbr gospodarczych, lecz także sprawiedliwego i godnego poziomu życia".

${ }^{63}$ Portal Spóldzielczy. Wersja z dnia 8. 05. 2007. http://www.spoldzielczosc.pl/modules.php?name $=$ News\&file $=$ article $\&$ sid $=292$

${ }^{64}$ Kapitał społeczny jest zestawem takich czynników kulturowych jak utrwalone tradycje, interesy indywidualne i grupowe, idee, normy moralne i religijne, stosunek do prawa, a także cechy psychospołeczne ludzi, gotowość do podejmowania ryzyka, inwestowania w przyszłość. G.

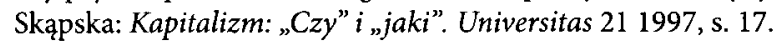

65 B. Fedyszak-RadziejowsKa, Jak polska wieś przez Brukselę do Polski wracała, (W:) III Rzeczpospolita w trzydziestu odstonach, pod red. A. Kostarczyka, Warszawa 2004, s. 260-262; A. LeOpOLD, Rolnictwo w procesie przemian i rozwoju gospodarki, Warszawa 1997, s. 33.

${ }_{66}$ Są to: usługi socjalne, usługi poprawiające jakość życia, kulturalne, środowiskowe (w tym opieka nad dziećmi i osobami starszymi), transport publiczny, sklepy, turystyka, spuścizna kulturalna, zagospodarowanie odpadów i innych. M. G. BRoDZIŃsKI, Dylematy rozwoju spótdzielczości w Polsce, Warszawa 1999, s. 222.

67 Ibidem s. 222.

${ }^{68}$ Np. zagrożonych bezrobociem, zatrudnienia absolwentów, pożyczek na podjęcie działalności na własny rachunek, pożyczek pracodawcom na zorganizowanie dodatkowych miejsc pracy J. Auleytner, Polska polityka spoleczna..., s. 227. 
W Danii i Holandii, wieloletnie sukcesy spółdzielczości w eksporcie artykułów rolno-spożywczych dały podstawę do stwierdzenia, że spółdzielnie mogą dobrze funkcjonować i być efektywnymi przedsiębiorstwami handlu zagranicznego ${ }^{69}$, czyli zdobyć swoją pozycję w warunkach rynkowych ${ }^{70}$.

Do rozwoju inicjatywy społecznej obywatele potrzebują funduszy i pełnej, dostępnej informacji. Konieczne jest zastosowanie właściwego środka w przekazie, by informacja jak najszybciej dotarła do głównego odbiorcy, jakim na dzień dzisiejszy jest rolnik, przedsiębiorca. Ograniczenia informacyjne i wynikające $\mathrm{z}$ tego trudności dla ludzi jako podmiotów gospodarujących powodują powstawanie dodatkowych kosztów ${ }^{71}$. Jeśli informacja jest niepełna, wybór nie może być racjonalny. Ekonomista $\mathrm{O}$. Williamson stwierdził, że zatajanie informacji obok oszustwa, kłamstwa, manipulowania faktami są działaniami oportunistycznymi, które należy rozumieć jako kierowanie się interesem własnym ze skłonnością do nieuczciwości. Ukrywanie informacji powoduje wzrost kosztów końcowych, Jeśli osoba prowadząca działalność gospodarczą chce być lepiej poinformowana, ponosi w związku z tym większe koszty ${ }^{72}$.

Autorka uważa, że w obecnych warunkach jest trafna uwaga S. Bratkowskiego: „Wielkie gospodarstwo może specjalizować się, najmując wysokiej klasy fachowców. Ale ta konkurencja nie musi małych, kilkuhektarowych gospodarstw wykończyć. Tyle że nie mogą one specjalizować się - w pojedynkę. Czy to drobiarze, czy hodowcy bydła mlecznego, plantatorzy lnu czy producenci ryb, muszą wiązać się ze sobą i - z Ośrodkami Doradztwa Rolniczego. Muszą się zorganizować. (...) Nieważne, jak się to nazwie. (...) Chodzi o związki, lokalne lub nawet międzywojewódzkie, ze wspólnym fachowym doradztwem i opieką weterynaryjną. $\mathrm{Z}$ wymianą doświadczeń i rozpowszechnianiem materiałów szkoleniowych - jak w dawnych kółkach rolniczych Wielkopolski" ${ }^{73}$.

W Polsce w warunkach gospodarki planowej w latach siedemdziesiątych XX wieku w okresie „zielonego światła dla rolnictwa” powstały ponad pięćdziesiąt spółdzielni branżowych, które zajmowały się produkcją trzody chlewnej. Istotą tych spółdzielni było zrzeszenie właścicieli indywidualnych gospodarstw rolnych, co umożliwiało im korzystniejsze warunki prowadzenia hodowli m.in. kredytowanie produkcji, które było bardziej dostępne dla osoby prawnej, zaopatrzenie w paszę, które w sposób dostateczny zaspokajało potrzeby produkcyjne zrzeszo-

69 Ibidem, s. 211.

70 S. Bratkowski stwierdzil, że: „Od lat w różnych krajach świata producenci rolni przejmowali role właścicieli przemysłu, który pracował na ich surowcu". Stefan Bratkowski, Zamiast krakać, czyli to wieś ma przyszłość. Strona z dnia 8 maja 2007. http://www.fcp.edu.pl/site2/bibl/b019.html.

7 M. ŁaWry NOWICz, Spóldzielnie a koncepcje neoinstytucjonalne. Ruch Prawniczy, Ekonomiczny i Socjologiczny, 32004 , s. 162-163.

72 Ibidem, s. 171-172.

73 Ibidem. 
nych rolników. Wówczas były to bardzo ważne czynniki umożliwiające produkcję na większą skalę. Spółdzielnia była korzystną formą zrzeszenia. Funkcję administracyjną pełnił prezes spółdzielni wybrany przez członków, rozliczenia prowadziła księgowa. Stanowiska prezesa administratora i księgowej były etatowe. Te dwie osoby mogły być równocześnie członkami spółdzielni. Prezes administrujący spółdzielnią nie podejmował decyzji. Zastępca prezesa pełnił funkcję społeczną, był wybierany spośród członków i upoważniony przez członków spółdzielni do podejmowania decyzji w imieniu członków. Koszty związane z prowadzeniem administracji, pokrywali członkowie. $W$ dzisiejszej sytuacji funkcjonowanie podobnych spółdzielni przystosowanych do warunków ekonomicznych Unii Europejskiej również sprawdziłoby się w takich sprawach jak wynegocjowanie ceny, wejście na rynek, zdobycie i utrzymanie stałych klientów.

W idei spółdzielczości są cechy, które sprawdzają się w warunkach demokratycznych, umożliwiają uczestniczenie w działalności gospodarczej, eliminują pośredników, ograniczają wpływ administracji, zmniejszają zagrożenie korupcją.

Rozwój spółdzielczości może stać się przyczynkiem do powstania klasy średniej. W Polsce brak jest polityki stanu średniego. Powszechnie jako stan średni jest określana grupa społeczna oparta na własności prywatnej, ekonomicznie niezależna od państwa, która tworzy miejsca pracy, pomnaża zasobność kraju ${ }^{74}$. Obecni polscy drobni przedsiębiorcy wywodzą się przede wszystkim z obszaru wiejsko-małomiasteczkowego. W małych i średnich przedsiębiorstwach znalazło zatrudnienie $60 \%$ tych, którzy stracili pracę $\mathrm{w}$ wyniku upadku przedsiębiorstw państwowych. $80 \%$ małych firm zostały założone ze środków własnych właścicieli, którzy pożyczki zaciągali u rodziny lub najbliższych przyjaciól. Udział banków w kredytowaniu przedsięwzięć gospodarczych był znikomy ${ }^{75}$.

Inicjatywa społeczna jest ważnym czynnikiem i powinna być kompatybilna ze wsparciem ekonomicznym: „(...) mała i średnia własność w rolnictwie, w rzemiośle, $\mathrm{w}$ rękodzielnictwie, $\mathrm{w}$ handlu i przemyśle powinna czuć się bezpieczna i doznawać poparcia; związki spółdzielcze powinny jej zapewnić korzyści, jakie daje wielkie przedsiębiorstwo; tam, gdzie wielkie przedsiębiorstwa jeszcze dzisiaj

J. Auleytner, Polska polityka spoleczna..., s. 261.

75 B. Fedyszak-Radziejowska, Powrót do Polski. Klasa średnia III RP. Arcana 12 1996, s. 28. Zależności pomiędzy dostępem do kredytu na korzystnych warunkach a rozwojem gospodarczym przedstawil prawie trzydzieści lat temu S. Bratkowski: „Jeśli przyjmiemy, że walczyć się będzie $z$ rzeczywistym niebezpieczeństwem, $i$ to uchwytnym, odpadnie problem kontroli nad pieniądzem „kreowanym” przez operacje kredytowe. Próbuje się ją zrealizować przez politykę drogiego pieniądza, która nigdy nie prowadzi do niczego innego, jak do stagnacji. Czymś innym jest bowiem sytuacja, gdy pieniądza naprawdę brakuje, a będący do dyspozycji pieniądz pracuje, czym innym zaś murowanie dostępu do pieniądza". S. Bratkowski, Oddalający się kontynent, Warszawa 1978, s. 244-245. 
okazują się bardziej produktywne, należy dać robotnikowi możność uzgodnienia kontraktu pracy z kontraktem spółki"76.

Hans H. Münkner badacz niemiecki stwierdził: „Brzmi to paradoksalnie, ale przyszłość spółdzielni jest związana z powrotem do ich korzeni ideowych i wewnętrznych sił rozwojowych. Spółdzielnie powinny motywować członków do samopomocy w rozwiązywaniu ich problemów, w zakresie których często bezradne jest zarówno państwo, jak i rynek. Muszą stworzyć lokalną dynamikę rozwoju, podejmować nowe zadania i wkraczać na nowe obszary działalności i dla tych celów mobilizować lokalne rezerwy. Potrzebne jest dostosowanie się nie do konkurencji, lecz do nowych warunków i potrzeb przy zachowaniu tożsamości spółdzielczej"77. Ze strony polskiej Stefan Bratkowski wskazał, konieczność pobudzenia inicjatywy przez włączenie do aktywnego współuczestniczenia w działalności spółdzielni i zapewnienia udziałów pracownikom jako sposób na restrukturyzację spółdzielczości wiejskiej. Bratkowski powołał się na tradycję spółdzielczości, która w Europie sięga trzystu pięćdziesięciu lat: „Spółdzielnie mleczarskie były własnością chłopów. Szefom i pracownikom mleczarni dawano udziały w spółkach czy też w spółdzielniach, żeby pracowali „na swoim”, nie „u kogoś, ale byli oni tylko współwłaścicielami, dbałymi o wspólny interes, nie zaś właścicielami wyłącznymi"78.

Autorka uważa, że w okresie, kiedy spółdzielczość odzyskuje uznanie w Europie należałoby skorzystać ze sprawdzonych doświadczeń innych krajów UE np. Danii, w których spółdzielczość jest rozwinięta i przynosi korzyści rolnikom-członkom. Skutecznymi sposobami przekazywania wiedzy z zakresu spółdzielczości i integracji społecznej mogą być szkolenia organizowane dla młodzieży i rolników polskich w innych krajach UE.

76 PIUs XII, Przemówienie radiowe z dnia 1 września 1944 r. AAS 36 (1944) 254 [nr 12]. Autorka cytuje za: Jan XXIII: Mater et magistra..., s. 36.

77 Autorka cytuje za B. STRUżex, Problemy strukturalnej przebudowy spóldzielczości w RFN a kwestia jej odbudowy w Polsce. Wieś i Państwo 4 1992, s. 174.

78 S. BRATKOWSKı, Zamiast krakać, czyli to wieś ma przyszłość. Strona z dnia 8 maja 2007. http:// www.fcp.edu.pl/site2/bibl/b019.html. 